\title{
BUSINESS JUDGEMENT RULE: KETENTUAN DAN PELAKSANAANNYA OLEH PENGADILAN DI INGGRIS, KANADA DAN INDONESIA
}

\author{
Yafet Yosafet Wilben Rissy* \\ Departemen Hukum Bisnis, Fakultas Hukum Universitas Kristen Satya \\ Jl. Diponegoro 52-60, Salatiga, 50711.
}

\begin{abstract}
This article discusses the provisions of business judgment rule (BJR) in the company law and the application of BJR by the courts in the United Kingdom (UK), Canada and Indonesia. In the UK and Canada, the courts have been long examined the appropriateness of directors' business decisions. Later, BJR was codified into the Canadian Business Corporations Act 2019, meanwhile, duty of care and fiduciary duties were codified into the UK 2006 Companies Law which implicitly regulates BJR. Indonesia adopts BJR in the Company Act 2007 but the courts rarely examine directors' business decisions and the adoption needs to be rearranged systematically.
\end{abstract}

Keywords: business judgment rule, directors, business decision, directors'duties and courts.

\section{Intisari}

Artikel ini membahas bagaimana dan kapan pengadilan menguji aturan penilaian bisnis (APS) dan bagaimana APS diatur dalam hukum perusahaan di Inggris Raya, Kanada, dan Indonesia. Pada pengadilan Inggris dan Kanada yang menganut tradisi hukum kebiasaan, APS telah lama diterapkan untuk menilai keputusan bisnis direktur. Baru-baru ini, APS dikodifikasikan ke dalam Undang-Undang Perusahaan Bisnis 2019. Sementara itu, tugas direktur untuk peduli dan tugas fidusia juga dikodifikasikan ke dalam UndangUndang Perusahaan Inggris 2006 yang secara implisit mengatur APS. Indonesia juga mengadopsi APS dalam Undang-Undang PT 2007 tetapi pengadilan jarang menguji keputusan bisnis direktur dan adopsi ini perlu diatur ulang secara lebih sistematis.

Kata Kunci: aturan penilaian bisnis, direktur, keputusan bisnis, tugas direktur, dan pengadilan.

\section{Pokok Muatan}

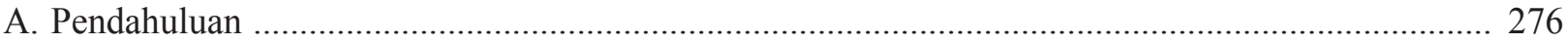

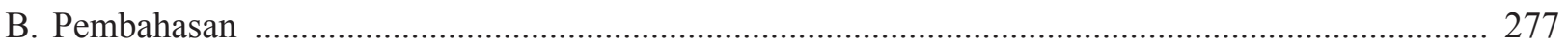

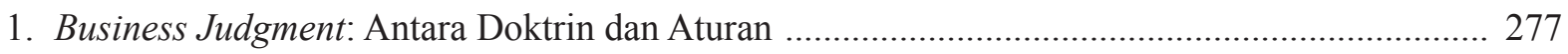

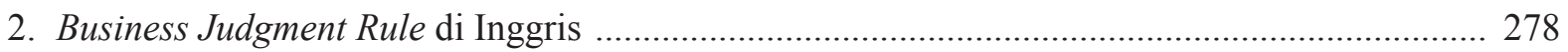

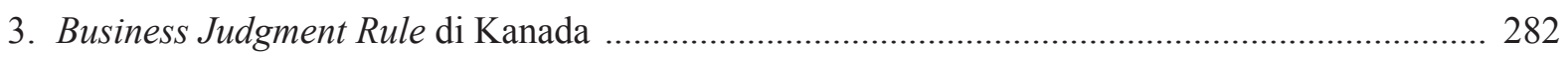

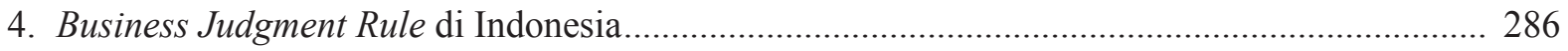

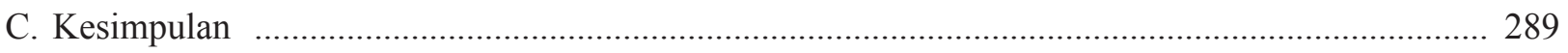

\footnotetext{
Alamat korespondensi: yafet.rissy@uksw.edu.
} 


\section{A. Pendahuluan}

Tugas seorang direktur merupakan amanat yang sulit. Di satu sisi, seorang direktur melalui keputusan atau tindakan bisnisnya mengemban misi untuk mengelola perusahaan dengan profesional untuk mendatangkan keuntungan bagi perusahaan, tetapi disisi lain keputusan bisnis seorang direktur penuh dengan resiko dan tidak jarang mendatangkan kerugian atau bahkan kebangkrutan perusahaan. Jika ini situasinya, bagaimana menilai batas pertanggungjawaban hukum dan pribadi direktur jika sebuah keputusan bisnis mendatangkan kerugian, hutang atau bahkan kebangkrutan perusahaan?

Perjalanan panjang untuk menguji keputusan atau tindakan bisnis direktur telah dilakukan oleh pengadilan di Inggris dan Kanada. Terdapat suatu masa dimana aturan penilaian bisnis (APB) atau business judgment rule (BJR) belum diatur secara tegas dalam Undang-Undang Perusahaan (UUP) di kedua negara tersebut, praktek pengujian terhadap BJR oleh pengadilan didasarkan pada tradisi common law (hukum kebiasaan) yang juga diletakkan fondasinya oleh pengadilan. Meskipun demikian, perdebatan seputar aspek kepastian hukum dan konsistensi penerapan BJR tetap saja mengemuka. Untuk itu, pada tahun 2006 dan 2019, Inggris dan Kanada memiliki prinsip-prinsip BJR yang dilahirkan oleh pengadilan kemudian dikodifikasikan dalam UUP di kedua negara tersebut yakni the UK Corporation Act 2006 dan dalam the CBCA 2019.

Sementara di Indonesia, sekalipun BJR telah diadopsi secara terbatas dalam Undang-Undang No. 40 Tahun 2007 tentang Perseoran Terbatas (UU PT 2007), nampaknya pengujian atas keputusan bisnis direktur oleh pengadilan belum mendapat perhatian serius. Hampir bisa dipastikan bahwa pengujian
BJR di pengadilan yang dimulai dari proses perdata melalui gugatan derivatif sebagaimana diamanatkan Pasal 97 ayat (6) UU PT 2007 tidak berjalan. Yang terjadi malah sebaliknya, pengujian atas keputusan bisnis direkur malah dilakukan melalui kasus tindak pidana korupsi dimana Mahkamah Agung Republik Indonesia (MA) baru saja mengejutkan dunia penegakan hukum di Indonesia dengan membebaskan Mantan Direktur Utama Pertamina, Karen Agustiawan dari segala dakwaan korupsi dengan menggunakan alasan dan pertimbangan bahwa keputusan bisnis Karen Agustiawan sebagai direktur telah sesuai dengan prinsip-prinsip BJR. ${ }^{2}$

Ketentuan dan pelaksanaan BJR di Inggris dan Kanada dianalisis dalam artikel ini karena di kedua negara ini keputusan bisnis direktur yang melanggar pinsip-pinrsip BJR telah diuji oleh pengadilan dalam jangka waktu lama dalam tradisi common law dan kemudian prinsip-prinsipnya dikodifikasikan dalam Undang-Undang Perusahaan terbaru di Inggris tahun 2006 dan di Kanada tahun 2019 untuk memberi jaminan kepastian hukum atas pengujian BJR. Pengalaman kedua negara ini diharapkan dapat memberikan masukan bagi Indonesia dalam menyikapi isu sejenis. Sementara itu, ketentuan dan pelaksanaan BJR di Indonesia juga dianalis untuk kelemahan adopsi BJR di UU PT 2007 dan sikap pengadilan di Indonesia atas pengujian keputusan bisnis direktur.

Artikel ini mengulas dua persoalan mendasar berupa kapan dan bagaimana pengadilan menguji penerapan BJR oleh direktur; dan bagaimana BJR dikodifikasikan dalam UUP di Inggris, Kanada dan Indonesia. Sebelum kedua isu utama di atas dibahas, perbedaan dan persamaan konsep BJR dan business judgment doctrine (BJD) terlebih dahulu diuraikan. Sementara itu, artikel ini juga mempermasalahkan adopsi BJR dalam UU PT 2007 di Indonesia dengan

\footnotetext{
Lihat s 170 (3)(4) the UK Companies Act 2006; lihat s 122 (1) (a)(b) CBCA 2019. Bandingkan Carlos Andres Laguado Giraldo, "Factors governing the Application of the Business Judgment Rule: An Empirical Study of the US, UK, Australia and the EU", en Vniversitas, Vol. 111, 2006, hlm. 134; Bandingkan juga Ponsford MP, “Corporate Governance and the Business Judgment Rule: Fiduciary Duties of Directors in Canada and the People's Republic of China". Journal of Civil Legal Science, Vol. 5, No. 1, Januari 2016, hlm. 2.

Detik.com, "MA Lepaskan Eks Dirut Pertamina Karen di Kasus Korupsi Rp 568 M", https://news.detik.com/berita/d-4931904/ma-lepaskaneks-dirut-pertamina-karen-di-kasus-korupsi-rp-568-m? ga=2.21407481.332223227.1583567161-84216239.1549435714, diakses 9 Maret 2020.
} 
menjelaskan sejumlah kelemahan mendasarnya. Artikel ini pada akhirnya menyajikan sejumlah rekomendasi konkrit bagi perubahan UU PT 2007 sepanjang terkait dengan adopsi BJR.

\section{B. Pembahasan}

1. Business Judgment: Antara Doktrin dan Aturan

Business judgment sebagai doktrin atau aturan merupakan salah satu ajaran utama dalam hukum perusahaan. ${ }^{3}$ Namun dalam praktek dan literatur, kedua konsep ini; business judgment sebagai doktrin (business judgment doctrine, BJD) dan business judgment sebagai aturan (BJR) seringkali disalahartikan, seolah keduanya memiliki arti yang sama. Ada ahli yang mencoba membedakan BJD dan BJR tetapi ada juga ahli yang berpendapat bahwa BJD dan BJR memiliki makna yang sama. Hensey, mencoba membedakan BJR dan BJD dengan berargumentasi bahwa BJR memberikan kekebalan bagi individu direktur dari tanggungjawab atas kerusakan yang berasal dari keputusan tertentu. ${ }^{4}$ Pendapat senada diberikan oleh Farrar yang mengatakan bahwa BJR merupakan sebuah aturan atau praduga tentang tidak adanya pertanggungjawaban (presumption of no liability) dari direktur. Sedangkan BJD, menurut Hensey, melindungi pengambilan keputusan itu sendiri, mengakui legitimasi dewan direktur sebagai pembuat keputusan dan penghormatan terhadap otonomi yudisial yang diberikan kepada dewan direktur. $^{6}$

Block et al menggarisbawahi tiga dasar pemikiran dari BJD. Pertama, pengakuan adanya kesalahan manusia. Kedua, pengakuan atas peran pengambilan resiko dalam keputusan bisnis.
Ketiga, menegaskan agar pengadilan tidak terjebak dalam pengambilan keputusan perusahaan dan manajemen yang kompleks dan terperangkap dalam tebakan kedua (second guess) yang pengadilan sendiri tidak siap untuk melakukannya?

BJD dan BJR pada dasarnya memiliki keterkaitan satu sama lainnya. McMillan berpendapat BJR adalah "sebuah doktrin yang diciptakan pengadilan untuk melindungi direktur dari pertanggungjawaban sipil pribadi atas keputusan yang dibuat atas nama perusahaan". ${ }^{8}$ Sementara itu, secara tradisional, Lori menegaskan bahwa BJR telah diakui sebagai standar pertanggungjawaban, yang menelisik kelayakan perlindungan BJR atas keputusan bisnis direktur setelah dilakukan sejumlah pengujian terhadap syarat tertentu. ${ }^{9}$ Jadi BJR itu doktrin yang dihasilkan pengadilan (pada awalnya), ketika undang-undang tidak atau belum memberikan definisi yang konkrit mengenai BJR. Oleh karena itu, BJR adalah BJD ataupun sebaliknya.

Terkait ciri fundamental dari BJR, ahli hukum perusahaan, Branson menjelaskan bahwa BJR memiliki setidaknya tiga aspek fundamental. Pertama, BJR dimaksudkan untuk mendukung tindakan manajer perusahaan atau tepatnya a safe harbour (pengaman/perlindungan) bagi tindakan direktur agar tindakan tersebut tidak disingkirkan karena telah memenuhi syarat. Kedua, dalam proses litigasi, BJR merupakan sarana untuk melestarikan sumber daya yudisial, sehingga pengadilan tidak terperosok untuk mengulangi keputusan yang secara inheren subyektif dan tidak cocok untuk hakim, karena hakim bukan pebisnis. Ketiga, BJR merupakan implementasi dari hukum kebijakan ekonomi luas, yang dibangun atas kebebasan

\footnotetext{
Stephen M. Bainbridge, “The Business Judgment Rule As Abstention Doctrine”, Vanderbilt Law Review, Vol. 57, No.1, Januari 2004, hlm. 83. Joseph Hinsey IV, "Business Judgment and The American Law Institute's Corporate Governance Project: The Rule, The Doctrine and The Reality", George Washington Law Review. Vol. 15 No. 4-5, Mei 1984, hlm. 609.

John Farrar, 2001, Corporate Governance Theories, Principles, And Practices, Oxford University Press, Oxford, hlm. 143.

Joseph Hinsey IV, Op. cit., hlm. 609.

Dennis J. Block, et al., 1987, The Business Judgment Rule - Fiduciary Duties of Corporate Directors and Officers, Clifton N.J., Prentice, hlm. $1-5$.

Lori Mcmillan, “The Business Judgment Rule as An Immunity Doctrine”. William And Mary Business Law Review, Vol. 4, No. 2, Agustus 2013, hlm. 521 .

Ibid.
} 
ekonomi dan dorongan untuk pengambilan resiko yang didasarkan pada informasi yang cukup. ${ }^{10}$ Belakangan ini, BJR dipakai juga untuk menilai tindakan direktur terkait pengambilalihan perusahaan yang dibawa ke pengadilan, dan BJR digunakan oleh perusahaan dan para pengacaranya untuk mengevaluasi dan merekomendasikan bahwa seharusnya pengadilan menolak gugatan derivatif. ${ }^{11}$

Ahli lainnya, Weinberger, berdasarkan analisisnya terhadap berbagai keputusan pengadilan di Amerika, mengemukakan empat alasan mendasar dari BJR. Pertama, kepakaran bisnis dan pengadilan. Pengadilan dalam sejumlah keputusannya menyatakan bahwa pengadilan tidak memiliki kualifikasi untuk mengadili keputusan bisnis dibandingkan dengan para pebisnis, yang memang telah diperlengkapi untuk membuat keputusan bisnis. Kedua, pengadilan sendiri mengakui bahwa BJR dimaksudkan untuk mendorong pengambilan resiko bisnis. Ketiga, efisiensi pengadilan. Pengadilan telah memutuskan bahwa demi efisiensi, pengadilan sebaiknya tidak menghabiskan sumber dayanya untuk mengadili keputusan bisnis yang sebenarnya diperbolehkan bagi dewan direktur. Keempat, penghormatan terhadap struktur bisnis. ${ }^{12}$

Berdasarkan sisi argumen ekonomi, membiarkan mesin tata kelola perusahaan berfungsi sebagaimana mestinya, sekalipun kadang membuat kesalahan, itu jauh lebih efisien dibandingkan dengan menginterupsi dan menggangu fungsi tim internal. Sedangkan dari sisi argumen struktur hukum, menghormati keputusan dewan direktur dipersyaratkan untuk menghormati struktur perusahaan, yang memberikan dewan direktur kekuasaan untuk mengambil keputusan. ${ }^{13}$

Uraian di atas menunjukan adanya hubungan erat antara BJR dan BJD yakni bahwa BJR dihasil- kan oleh doktrin pengadilan. Jadi BJR sama dengan BJD dan seringkali dalam praktek, sekalipun yang dirujuk adalah BJD tetapi ditulis BJR. Tetapi perbedaannya adalah bahwa BJR adalah aturan yang memberi perlindungan bagi direktur dalam mengambil atau tidak mengambil keputusan bisnis tertentu. Sementara BJD membatasi pengadilan untuk tidak melakukan penilaian terhadap keputusan bisnis karena pada dasarnya pengadilan tidak diperlengkapi untuk melakukan tugas tersebut. Dengan kata lain, dalam bahasa Hensey, BJR melindungi direktur dari pertanggungjawaban hukum personal sedangkan BJD melindungi keputusan bisnis direktur itu sendiri. ${ }^{14}$ Jadi, dalam pandangan Penulis, BJR sebenarnya merupakan ajaran/doktrin yang dihasilkan oleh pengadilan dalam tradisi common law yang kemudian dijadikan aturan atau parameter untuk menguji keputusan bisnis direktur (BJR). Selanjutnya, penulis akan menggunakan BJR karena istilah ini lebih banyak dipakai dalam putusan-putusan pengadilan maupun dunia literatur.

\section{Business Judgment Rule di Inggris}

Sejarah pertumbuhan dan perkembangannya di Inggris menunjukkan bahwa BJD telah sejak lama diakui atau dikenal dalam hukum perusahaan. Dalam BJD, pengadilan tidak diperbolehkan menebak keputusan bisnis yang diambil oleh direktur. ${ }^{15}$ Dengan demikian, di Inggris, yang berkembang adalah business judgment doctrine (BJD) bukan business judgment rule (BJR). Sesungguhnya di Inggris, BJR kurang mendapatkan tempat di pengadilan di Inggris, karena adanya doktrin bahwa pengadilan tidak boleh mengintervensi keputusan bisnis jika tidak mala fide (bad faith) atau itikad jahat ${ }^{16}$ dan karena memang sejak awal

\footnotetext{
10 Douglas M. Branson, “The Rule at Isn’t A Rule - E Business Judgment Rule”, Alparaiso University Law Review, Vol. 36, No. 34, Summer 2002, hlm. 632 .

Ibid.

12 Lael Daniel Weinberger, “The Business Judgment Rule and Sphere Sovereignty”, Thomas M. Cooley Law Review, Vol. 27, No. 2, Mei 2010, hlm. 290-292.

Ibid.

Joseph Hinsey IV, Op. cit., hlm. 609

John Farrar, Op. cit., hlm.139.

Devlin V Slough Estates Ltd [1983] BCLC 497 At 503-504, dalam Andrew Keay And Joan Loughrey, "The Concept of Business Judgment". Legal Studies, Vol. 39, No. 1, Maret 2019, hlm. 38.
} 
perkembangannya di Inggris tidak ada undangundang yang mengatur soal BJR. Jika dilakukan pengujian BJR, dikuatirkan pengadilan akan melakukan kesalahan penilaian (hindsight bias) dan menciptakan masalah institusi bagi pengadilan. ${ }^{17}$

Alasan lainnya ialah bahwa tugas direktur untuk bertindak dengan kepedulian dan keahlian (duty of care and skill) adalah sebuah konsep yang subjektif karena tergantung pada keahlian pribadi direktur. Doktrin ini terlihat dalam kasus Re City Equitable Fire Insurance Co Ltd di tahun 1925, Hakim Romer menyatakan bahwa "seorang direktur tidak perlu menunjukkan dalam kinerja tugasnya suatu tingkat keahlian yang lebih besar daripada yang mungkin diharapkan dari pengetahuan dan pengalaman orang lain". ${ }^{18}$ Doktrin yang memahami keahlian direktur secara subjektif ini membuat pengadilan ekstra hati-hati dalam menilai pelanggaran duty of care and skill direktur. Pertimbangan lain, sebagaimana terlihat dalam kasus Re Barings Plc \& Others tahun 1999 adalah bahwa konsep duty of care and skill merupakan sebuah standar yang fleksibel yang ditentukan berdasarkan analisis terhadap besaran tiap perusahaan, khususnya peran yang sesungguhnya dari direktur dalam manajemen perusahaan. ${ }^{19}$

Menurut pandangan Enriques, Hansmann, dan Kraakman, di Inggris sejak tahun 1974, nampaknya BJR sebagai aturan non undangundang yang lunak telah diterapkan dalam kasus Howard Smitth v Ampol Petroleum. ${ }^{20}$ Lagi pula, dengan semakin berkembang pesatnya investor institusional karena diversifikasi pemegang saham yang ekstensif di Inggris, penerapan BJR semakin memungkinkan. Dalam struktur pemegang saham yang terdiversifikasi memungkinkan pemegang saham tersebar ke berbagai negara sehingga dalam hal pemegang saham merasa dirugikan oleh keputusan direktur, investor institutional dengan lebih mudah membawa sebuah keputusan bisnis direktur untuk diuji dari aspek BJR. ${ }^{21}$

Sekalipun demikian, yang berkembang di Inggris bukan BJR melainkan pengujian yang dilakukan oleh pengadilan terhadap tugas common law direktur yakni duty of care. Dalam konteks menguji tindakan direktur yang melakukan transaksi dengan pihak ketiga, misalnya, pengadilan lebih memilih menggunakan istilah commercial judgment daripada business judgment, sebagaimana terlihat dalam kasus Cobden Investments Ltd v RWM Langport Ltd, Moxon v Litchfield, dan ARB International Ltd v Baillie. ${ }^{22}$

Istilah commercial business juga dipakai pengadilan di Inggris yang merujuk kepada pengambilan keputusan yang lebih luas. Dalam kasus, $F \& C$ Alternative investmen (Holding) Ltd $v$ Barthelemy, pengadilan menyatakan bahwa perusahaan diperbolehkan mengambil keputusan strategis untuk memotong biaya dengan cara memberhentikan staf karena produk perusahaan tidak diminati pasar dan dalam kasus Oak Investment Partners XII v Boughtwood tahun 2009, perusahaan boleh tidak menindaklanjuti peluang diluar bisnis utama perusahaan. ${ }^{23}$ Selain itu, dalam konsepsi pengadilan di Inggris, penting untuk diperhatikan bahwa direktur perlu menggunakan pengalaman dan kemampuannya secara layak sebelum mengambil keputusan bisnis. Jika tidak, ini merupakan sebuah

17 Aurelio Gurrea-Martinez, "Re-Examining the Law and Economics of The Business Judgment Rule: Notes for Its Implementation in Non-US Jurisdictions", Journal of Corporate Law Studies, Vol. 18, No. 2, July 2018, hlm. 423.

18 Re City Equitable Fire Insurance Co (1925) Ch 407. Substansi Putusan Ini Dapat Dilihat Di Https://Www.Revolvy.Com/Page/Re-CityEquitable-Fire-Insurance-Co. Diakses 2 September 2019.

19 Re Barings Plc \& Others, 1999, 1 BCLC 433, dalam Demetra Arsalidou, "Objectivity Vs Flexibility in Civil Law Jurisdictions and The Possible Introduction of The Business Judgment Rule In English Law", The Company Lawyer, Vol. 24, No. 8, Agustus 2003, hlm. 230.

20 Luca Enriques, Henry Hansmann, and Reinier Kraakman, 2009, The Basic Governance Structure: The Interests of Shareholders as a Class, in Kraakman et al, The Anatomy of Corporate Law: A Comparative and Functional Approach, 3rd edn, Oxford University Press, Oxford, hlm. 79-80.

21 John Armour and David Skeel, "Who Should Write Hostile Takeovers, and Why? The Peculiar Divergence of US and UK Takeover Regulation”, Georgetown Law Journal, Vol. 95, No. 7, Agustus 2007, hlm. 1756-1766.

22 Andrew Keay And Joan Loughrey, Op. cit., hlm. 45.

23 Ibid. 
pelanggaran atas duty of care. ${ }^{24}$

Terkait tugas direktur untuk bertindak dalam kewenangannya (intra vires), Pengadilan Banding (Court of Appeal) dalam kasus Bishopgate Inv. Manag. Ltd vs. Maxwell, di tahun 1994, menegaskan bahwa tugas tersebut tidak hanya harus sesuai konstitusi perusahaan tetapi juga tujuan perusahaan. Pengadilan Banding juga memutuskan bahwa pelanggaran terhadap tugas untuk bertindak dalam kewenangannya (intra vires) tidak hanya disebabkan oleh adanya unsur kealpaan (negligence) tetapi juga penyalahgunaan aset perusahaan. ${ }^{25}$

Praktek untuk menilai commercial judgment direktur di Inggris dapat dilakukan juga melalui gugatan derivatif pemegang saham atas direktur. Gugatan derivatif ini hanya bisa dilakukan jika memenuhi dua syarat utama yakni perusahaan telah dikuasai oleh direktur atau pihak manajemen yang telah melakukan kesalahan yang merugikan pemegang saham dan keputusan bisnis yang mengandung kesalahan yang dipersoalkan tersebut tidak mendapatkan persetujuan pemegang saham. Dalam kasus Prudential Assurance Co. v. Newman Industries, Ltd., pengadilan menyatakan bahwa elemen kasalahan tersebut dapat dibuktikan melalui penguasaan yang efektif dari direktur atau pejabata perusahaan lainnya yang bertindak ceroboh sekalipun mereka tidak menguasai suara mayoritas pemegang saham. ${ }^{26}$ Dalam kasus ini, Vinelot berpendapat bahwa tindakan yang salah oleh direktur atau pejabat perusahaan lainnya ini dapat dikategorikan sebagai 'fraud' dimana direktur telah memperoleh manfaat atau keuntungan pribadi dari pelanggaran tersebut. ${ }^{27}$ Dengan kata lain tanpa membuktikan adanya 'fraud' yakni perolehan keuntungan pribadi oleh direktur, commercial judgment atas tindakan bisnis direktur melalui gugatan derivatif sulit dikabulkan Pengadilan.

Bahkan, tidak hanya direktur yang harus dibebaskan, pejabat perusahaan atau pekerja lainnya di perusahaan yang dituduh telah melakukan tindakan bisnis yang merugikan perusahaan dan kerenanya harus bertanggungjawab namun tindakan tersebut telah dilakukan dengan itikad baik dan memiliki alasan yang cukup ataupun tidak memperoleh manfaat pribadi dari keputusan bisnis tersebut, mereka harus dibebaskan. Penegasan di atas dituangkan dalam s 1157 (1) the UK Company Law 2006 yang menyatakan bahwa:

If in proceedings for negligence, default, breach of duty or breach of trust against (a) an officer of a company, or (b) a person employed by a company as auditor (whether he is or is not an officer of the company), it appears to the court hearing the case that the officer or person is or may be liable but that he acted honestly and reasonably, and that having regard to all the circumstances of the case (including those connected with his appointment) he ought fairly to be excused, the court may relieve him, either wholly or in part, from his liability on such terms as it thinks fit.

Terlepas dari fakta bahwa pengadilan di Inggris lebih menggunakan istilah commercial judgment dalam menilai kelayakan pelaksanaan tugas common law direktur yakni duty of care, dalam tingkat tertentu pengaruh BJR versi Amerika ${ }^{28}$ telah turut mempengaruhi pengadilan di Inggris untuk

24 Ibid.

25 Adina Ponta And Radu N. Catana, "The Business Judgement Rule and Its Reception in European Countries", The Macrotheme Review, Vol. 4, No. 7, Winter 2015, hlm. 130.

26 Geoffrey Miller, "Special Symposium Issue: Political Structure and Corporate Governance: Some Points of Contrast Between the United States and England", Columbia Business Law Review, Vol. 1, Winter 1998, hlm. 57.

27 Christopher Riley, "Derivative Claims and Ratification: Time to Ditch Some Baggage", Legal Studies, Vol. 34, No. 4, Desember 2013, hlm. 590.

28 Terkait pembahasan BJR Di Amerika, lihat antara lain Lyman P.Q. Johnson, "Corporate Officers and The Business Judgment Rule", Business Lawyer, Vol. 60, No. 2, Februari 2005, hlm. 441-453; Lyman P.Q. Johnson, Unsettledness in Delaware Corporate Law: Business Judgment Rule, Corporate Purpose, Delaware Journal of Corporate Law, Vol. 38, No. 2, Spring 2013, hlm. 410-431; Lynn A., Stout, "In Praise of Procedure: An Economic and Behavioral Defense Of Smith V. Van Gorkom and The Business Judgment Rule", Northwestern University Law Review, Vol. 96, No. 2, Winter 2002, hlm. 675-678; Yafet Y. W. Rissy, "Ketentuan dan Pelaksanaan Business Judgement Rule di Amerika, Australia dan Indonesia”, Jurnal Masalah-Masalah Hukum, Vol. 49, No. 2, April 2020, hlm. 161-164; lihat juga Yafet Y. W. Rissy, 2020, Corporate Governance: Kajian Teori, Konsep dan Praktek Terbaik Lintas Yurisdiksi, Perspektif International Serta Tantangannya, Griya Media, Salatiga, hlm. 307-312. 
menguji keputusan bisnis direktur. Pengadilan di Inggris tidak dapat menguji keputusan bisnis direktur jika direktur telah bertindak dengan jujur dan memiliki alasan yang cukup, ${ }^{29}$ utamanya jika tindakan bisnis direktur tersebut telah mengabdi pada kepentingan pemegang saham. ${ }^{30}$

Mengingat perkembangan di atas, sekalipun BJR tidak digunakan secara eksplisit di Inggris, catatan perlu diberikan terkait kodifikasi duty of care dan tugas fidusia dalam the UK Companies ACT 2006 karena dalam tugas-tugas direktur inilah konsep BJR secara tidak langsung diakui. Untuk pertama kalinya dalam sejarah, doktrin terkait tugas common law direktur yakni duty of care yakni tugas untuk melaksanakan tugas dengan kepedulian dan tugas fidusia yakni tugas untuk bertindak dengan itikad baik dan untuk kepentingan terbaik perusahaan dikodifisikasikan ke dalam the UK Companies Act 2006. Konsekuensi dari kodifikasi ini, pengadilan tidak lagi semata mendasarkan diri pada interpretasi yang dituangkan dalam berbagai keputusan yang sudah ada, tetapi juga harus memperhatikan arahan dari the UK Companies Act 2006.

The UK Companies Act 2006 menegaskan tujuh tugas utama direktur yakni a) tugas untuk bertindak dalam kewenangannya (s 171) sesuai konstitusi perusahaan dan tujuan perusahaan; b) tugas untuk mempromosikan keberhasilan perusahaan (s 172) dimana di dalamnya terdapat tugas untuk bertindak dengan itikad baik dan untuk kepentingan terbaik perusahaan; c) tugas untuk melakukan penilaian atau keputusan yang independen (s 173); d) tugas untuk melaksanakan tugas dengan kepedulian, berdasarkan keahlian dan kehatian-hatian (s 174); e) tugas untuk menghindari konflik kepentingan (s 175); f) tugas untuk tidak menerima manfaat dari pihak ketiga (s 176); g) tugas untuk menyatakan adanya kepentingan dalam transaksi atau pengaturan yang diusulkan ( $\mathrm{s} 177$ ).

Menarik untuk diperhatikan bahwa s 170 (3) the UK Companies Act 2006 menyatakan bahwa tugas direktur yang dikodifikasi ini dimaksudkan untuk menggantikan aturan-aturan common law dan prinsip ekuitabel yang terkait dengan tugas direktur. Namun demikian, s 170 (4) the UK Companies Act 2006 mengingatkan bahwa tugas fidusia direktur harus diinterpretasikan dan diaplikasikan dengan cara yang sama sebagaimana dalam aturan common law dan prinsip ekuitabel dimana dasar tugas-tugas direktur ini diletakan dan mensyaratkan pengadilan untuk memperhatikan aturan-aturan common law dan prinsip ekuitabel dalam menginterpretasikan dan melaksanakan tugas umum direktur tersebut. The UK Companies Act 2006 tidak mendefinisikan atau membuat parameter yang ekplisit terkait BJR atau tidak mengakomodasi BJR. Hal ini sejalan dengan rekomendasi Laporan Komisi Hukum yang mengatakan bahwa Inggris tidak perlu mengadopsi BJR dalam undang-undangnya karena sudah ada BJR (doktrin) yang tidak langsung (implied) atau tidak tertulis (unwritten) yang ditemukan dalam penolakan Pengadilan untuk meninjau keputusan majanemen yang dibuat dalam itikad baik dan untuk tujuan yang tepat/layak. ${ }^{31}$

Sekalipun demikian, dalam pandangan penulis jika dicermati s 174 yang dengan eksplisit menyatakan bahwa direktur harus melaksanakan tugasnya dengan kepedulian, keahlian dan kehatihatian sebagaimana seharusnya diharapkan dilakukan seseorang dengan kehati-hatian dengan memperhatikan pengetahuan, keahlian, dan pengalamannya, maka rumusan ini sesungguhnya menyinggung atau terkait dengan commercial judgment yang umumnya telah digariskan oleh pengadilan di Inggris sebagaimana telah dibahas di atas.

Oleh karena itu, jika ketujuh tugas utama

\footnotetext{
29 Bryan Horrigan, "Directors' Duties and Liabilities — Where Are We Now and Where Are We Going in The UK, Broader Commonwealth, And Internationally?", International Journal Of Business And Social Science, Vol. 3, No. 2, Januari 2012, hlm. 25.

30 Carlos Andrés Laguado Giraldo, Op. cit., hlm. 147.

31 Demetra Arsalidou, Op. cit., hlm. 231.
} 
direktur menuurt The UK Companies Act 2006 dipakai untuk menilai syarat-syarat utama BJR(versi Canada) atau commercial judgment (versi Inggris), hampir dapat dipastikan bahwa sesungguhnya berbagai ketentuan di atas telah merangkum alasan bagi adanya commercialjudgment di Inggris. Artinya untuk melihat apakah direktur telah melaksanakan commercial judgment atau BJR dengan baik, perlu dipastikan bahwa dalam keputusan bisnis tersebut harus: a) mengandung itikad baik; b) tidak bermuatan konflik kepentingan; c) mengandung unsur kepedulian, keahlian dan kehati-hatian; d) keputusan yang independen (rasional dan obyektif); e) tidak memberi direktur manfaat yang tidak seharusnya diterima; f) keputusan melayani kepentingan terbaik perusahaan.

Nampaknya pembuat Undang-Undang Perusahaan di Inggris menyadari bahwa penilaian atas ketepatan dan kepatutan commercial judgement direktur tidak dapat dilepaskan dari tugas untuk peduli dan tugas fidusia direktur. Dalam konteks ini, pendapat Giraldo yang menyatakan BJR dapat dipahami sebagai doktrin yang melindungi direktur dari tanggungjawab pribadi hanya ketika direktur telah bertindak dengan itikad baik, dengan penuh kepedulian dan dalam kewenanganya (intra vires $)^{32}$ menjadi relevan di Inggris. Dengan kata lain, sepanjang direktur telah bertindak dengan itikad baik dan tanpa secara sengaja bertindak melawan hukum maka direktur tidak dapat dimintai pertanggunjawaban atas keputusan direktur yang salah. ${ }^{33}$

Pengadilan di Inggris dihadapkan pada tantangan yang lebih serius dalam menginterpretasi dan melaksanakan commercial judgment para direktur. Di satu sisi, pengadilan perlu konsisten sesuai arahan kodifikasi tugas untuk peduli dan keahlian (common law duties) dan fidusia direktur dalam the Companies Act 2006. Di sisi lain, pengadilan tidak boleh melupakan standar yang telah dihasilkan dalam common law dan prinsip keadilan yang dihasilkan dalam equity principles. Secara singkat dapat dijelaskan bahwa equity principles adalah standar atau nilai keadilan yang dihasilkan oleh Pengadilan Keadilan (Equity Court) di Inggris. Proses di Pengadilan Keadilan (equity court) akan dilakukan jika ada pihak yang merasa bahwa putusan Pengadilan Common Law tidak memberi atau menjamin keadilan yang sesungguhnya. Equtiy Court dapat menghukum atau merevisi putusan Pengadilan Common Law yang mengandung cacat atau kesalahan. ${ }^{34}$

\section{Business Judgment Rule di Kanada}

Pendekatan BJR di Kanada, sebagaimana di Inggris, merupakan pengujian terhadap tugas common law direktur yakni duty of care direktur dan tugas fidusia direktur. Namun, patut diakui bahwa BJR di Kanada telah dipengaruhi secara nyata ${ }^{35}$ oleh rumusan BJR yang disampaikan oleh Mahkamah Agung Delaware di Amerika dalam kasus Arranson v Lewis tahun 1984 yang menyatakan bahwa:

BJR adalah sebuah praduga bahwa dalam membuat sebuah keputusan bisnis, direktur perusahaan bertindak berdasarkan informasi, dengan itikad baik dan dengan keyakinan jujur bahwa tindakan yang diambil adalah demi kepentingan terbaik perusahaan. Jika tidak ada penyalahgunaan diskresi, keputusan itu akan dihormati oleh Pengadilan. Beban ada pada pihak yang menantang keputusan untuk menetapkan fakta yang membantah anggapan tersebut. ${ }^{36}$

\footnotetext{
Carlos Andrés Laguado Giraldo, Op. cit., hlm. 115.

Demetra Arsalidou, Op. cit., hlm. 230.

Untuk Memahami Konsep Equity Principle Lebih Lanjut Agar Dilihat Tulisan Klasik Lord Henry Home Kames, Principles of Equity, 16961782. Materi ini dapat diakses di <Https:/Quod.Lib.Umich.Edu/E/Ecco/004841431.0001.000/1:8?Rgn=Div1;View=Fulltext $>$. Diakses 2 September 2019

35 Pamela L. Hu, \& Russell C. Silberglied, "From Production Resources to Peoples Department Stores: A Similar Response by Delaware and Canadian Courts on the Fiduciary Duties of Directors to Creditors of Insolvent Companies", Journal of Business and Technology Law, Vol. 1, No. 2, 2007, hlm. 466; John Howard, "Takeover battles and the business judgment rule: recent American case law development", Canadian Business Law Journal, Vol. 11, No. 4, Maret 1986, hlm. 445; Deborah A. Demmoth, “Directors' Duty of Care and the Business Judgment Rule: American Precedents and Australian Choices”, Bond Law Review, Vol. 4, No. 2, 1992, hlm. $134-135$.
} 
Selanjutnya di Kanada, penerapan BJR tidak dapat dilepaskan dari tugas duty of care telah dikodifikasikan dalam s 122 (1) (b) the CBCA 2019 yakni tugas direktur untuk melakukan tugas dengan penuh kepedualian dan tugas fidusia diatur dalam s 122 (1) (a) the CBCA 2019 yakni tugas firektur untuk bertindak dengan itikad baik untuk kepentingan terbaik perusahaan. Untuk melihat bagaimana pengadilan di Kanada menafsirkan dan melaksanakan BJR baik menurut common law maupun menurut the CBCA 2019 ataupun UU Perusahaan Kanada sebelumnya, perlu dilihat sejumlah putusan fenomenal yang dikeluarkan oleh Mahkamah Agung Kanada, yang kemudian menjadi referensi utama BJR di Kanada.

Sebagaimana di Inggris dan Amerika, di Kanada BJR mengakui kompleksitas bisnis perusahaan dan operasinya, dan BJR menghormati keputusan bisnis direktur, yang dianggap memiliki keahlian dan integritas yang dipersyaratkan untuk bertindak dengan cara yang wajar. BJR juga mengakui keterbatasan dan kurangnya keahlian pengadilan untuk menguji keputusan bisnis direktur. ${ }^{37}$ Prinsip BJR di Kanada di atas ditegaskan oleh Pengadilan Banding Otario tahun 1998 dalam kasus Maple Leaf Foods v Schneider Corp, Pertimbangan Pengadilan Banding Otario di atas kemudian dirujuk lagi oleh Mahkamah Agung Kanada di tahun 2007 dalam kasus Kerr v Danier Leather Inc., ${ }^{38}$ dimana dalam pertimbangannya, Pengadilan di Kanada dengan padat dan jelas menyatakan bahwa:

'...Pengadilan harus yakin bahwa direktur telah bertindak dengan masuk akal dan jujur. Pengadilan ingin melihat bahwa manajemen membuat keputusan bisnis yang masuk akal bukan keputusan yang sempurna... Sepanjang direktur telah memilih satu dari alternatif keputusan yang masuk akal, keputusan bisnis dewan direktur harus dihormati' ${ }^{39}$

Demikian pula, dalam kasus Peoples Department Stores Inc. (Trustee of) v. Wise di tahun $2004,{ }^{40}$ Mahkamah Agung Kanada memperluas prinsip umumnya terkait BJR yang mirip dengan penerapan penilaian keputusan bisnis (business decision) di Inggris, yakni bahwa pengadilan menolak untuk melakukan tebakan kedua (second guest) atas keputusan bisnis (business judgment) yang dilakukan direktur ketika keputusan yang dipersoalkan tersebut berada dalam wilayah yang masuk akal, bertindak hati-hati dan berdasarkan informasi yang cukup. ${ }^{41}$

Paragraph 67 dari putusan di atas, Mahkamah Agung Kanada menyatakan dengan tegas sebagai berikut:

Direktur dan pejabat tidak akan dianggap melanggar duty of care berdasarkan s 122 (1) (b) CBCA jika mereka bertindak dengan hati-hati dan berdasarkan informasi yang wajar. Keputusan yang mereka buat harus merupakan keputusan bisnis yang wajar yang dengan memperhatikan semua keadaan yang diketahui atau seharusnya diketahui oleh para direktur atau pejabat. Dalam menentukan apakah direksi telah bertindak dengan cara yang melanggar duty of carenya, perlu diulangi bahwa kesempurnaan tidak dituntut. Pengadilan tidak cocok dan harus menolak menebak penerapan keahlian bisnis terhadap pertimbangan yang terlibat dalam pengambilan keputusan perusahaan, tetapi pengadilan mampu, berdasarkan fakta dari setiap kasus, untuk menentukan apakah tingkat kehati-hatian dalam pengambilan

36 Supreme Court of Delaware. (1984). Supreme Court of Delaware Aronson v. Lewis, 473 A.2d 805, 812 (Del. 1984) Decided: March 1, 1984, IV. https://law.justia.com/cases/delaware/supreme-court/1984/473-a-2d-805-4.html. Diakses pada 30 Juli 2020.

37 Vasudev, P.M., "Corporate Stakeholders in Canada-An Overview and a Proposal", Ottawa Law Review, Vol. 45, No. 1, Spring 2014, hlm. 156.

38 Kerr v. Danier Leather Inc., 2007 SCC 44 (CanLII), [2007] 3 SCR 331. Paragraph 56. Putusan ini dapat dilihat di https://www.canlii.org/en/ $\mathrm{ca} / \mathrm{scc} / \mathrm{doc} / 2007 / 2007 \mathrm{scc} 44 / 2007 \mathrm{scc} 44 . \mathrm{html}$, diakses 30 Juli 2020.

39 Maple Leaf Foods Inc. v. Schneider Corp. (1998), 1998 CanLII 5121 (ON CA), 42 O.R. (3d) 177 (C.A.). Review atas putusan ini dapat dilihat di https://www.canlii.org/en/on/onca/doc/1998/1998canlii5121/1998canlii5121.html. Diakses 30 Juli 2020.

40 Peoples Department Stores Inc. (Trustee Of) V. Wise, [2004] SCC 68, [2004] 3 SCR, Paragraph 46, Https://Scc-Csc.Lexum.Com/Scc-Csc/ Scc-Csc/En/Item/2184/Index.Do, diakses 1 September 2019.

41 Ibid. 
keputusan mencapai apa yang diklaim sebagai keputusan bisnis yang wajar pada saat keputusan itu dibuat. ${ }^{42}$

Jika dicermati rumusan putusan di atas, sekalipun pengadilan cenderung menolak gugatan terhadap direktur dengan alasan telah melanggar duty of care karena pengadilan tidak siap untuk itu, namun ditegaskan bahwa pengadilan mampu, berdasarkan fakta yang ada, menentukan tingkat ketepatan kehati-hatian dan kecermatan dalam mengambil keputusan bisnis yang masuk akal atau wajar pada saat keputusan itu dilakukan.

Pengujian di Kanada juga dapat dilakukan atas tugas fidusia direktur yakni untuk bertindak dengan itikad baik demi kepentingan terbaik perusahaan sebagaimana secara wajar dilakukan oleh orang lain dalam situasi yang dapat diperbandingkan sebagaimana dimaksud dalam s 122 (1) (a) the CBCA 2019. Menarik untuk diperhatikan bahwa masih dalam kasus yang sama, yakni Peoples Department Stores Inc. (Trustee of) v. Wise, Pengadilan memberi pertimbangan yang kembali menguatkan tugas fidusia direktur dan bahkan menambahkan unsur-unsur dalam tugas fidusia direktur sebagaimana diatur dalam s 122 (1) (a) the CBCA 2019. Pernyataan pengadilan selengkapnya sebagai berikut:

Tugas fidusia berdasarkan undang-undang mewajibkan direktur dan pejabat untuk bertindak jujur dan dengan itikad baik berhadaphadapan dengan perusahaan. Mereka harus menghormati kepercayaan dan kepercayaan yang telah ditempatkan di dalam mereka untuk mengelola aset perusahaan dalam mengejar realisasi tujuan perusahaan. Mereka harus menghindari konflik kepentingan dengan perusahaan. Mereka harus menghindari penyalahgunaan posisi mereka untuk mendapatkan keuntungan pribadi.
Mereka harus menjaga kerahasiaan informasi yang mereka peroleh berdasarkan posisi mereka. Direktur dan pejabat harus melayani perusahaan tanpa pamrih, jujur dan loyal. ${ }^{43}$

Hakikat putusan di atas sebenarnya menunjukan adanya penegasan agar direktur menghindari kecenderungan mengambil untuk mengambil keutungan dari keputusan bisnisnya dengan mengorbankan kepentingan dan kesejahteraan pemegang saham (agency cost). ${ }^{44}$ Dalam konteks ini, Easterbrook dan Fischel menilai bahwa BJR merupakan doktrin mewajibkan pengadilan untuk tidak campur tangan (a hands-off approach) atas keputusan bisnis direktur kecuali direktur mengambil untung dari keputusan bisnisnya. ${ }^{45}$

Jika diperhatikan rumusan pendapat pengadilan baik atas pengujian duty of care maupun atas pengujian tugas fidusia di atas, Pengadilan telah dengan jelas mengombinasikan dan memastikan unsur-unsur yang terkandung dalam duty of care dan tugas fidusia direktur yakni bahwa direktur dalam melakukan keputusan bisnis harus a) penuh kehatihatian, kepedulian dan keahlian; b) berdasarkan informasi yang cukup; c) bertindak jujur dan dengan itikad baik; d) mengelola perusahaan untuk mencapai tujuan perusahaan; e) menghidari konflik kepentingan; f) menghindari penyalahgunaan posisi sebagai direktur untuk memperoleh manfaat pribadi; g) menjaga rahasia perusahaan; dan h) melayani perusahaan tanpa pamrih, jujur dan loyal.

Menurut pandangan Penulis, unsur-unsur di atas tidak lain merupakan common law BJR di Kanada. Keputusan bisnis yang tidak memenuhi unsur-unsur di atas merupakan pelanggaran atas BJR dan atas pelanggaran tersebut pengadilan dapat mengadili keputusan bisnis yang dilakukan direktur.

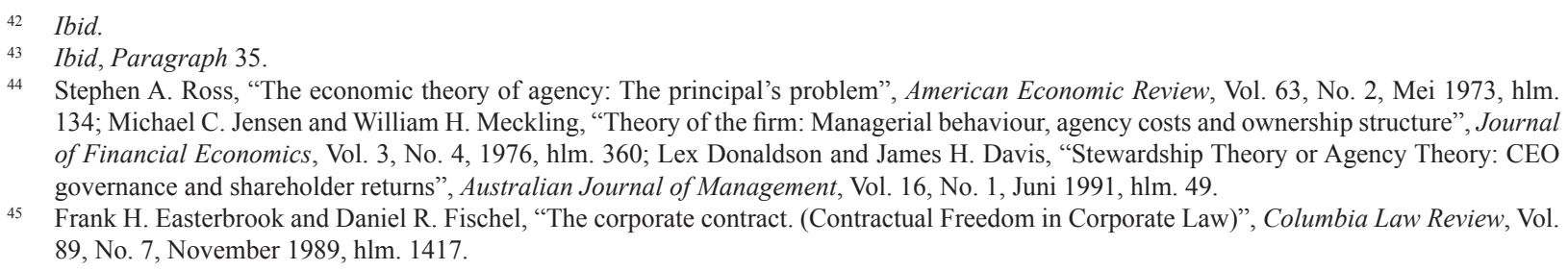
134; Michael C. Jensen and William H. Meckling, "Theory of the firm: Managerial behaviour, agency costs and ownership structure", Journal of Financial Economics, Vol. 3, No. 4, 1976, hlm. 360; Lex Donaldson and James H. Davis, "Stewardship Theory or Agency Theory: CEO governance and shareholder returns", Australian Journal of Management, Vol. 16, No. 1, Juni 1991, hlm. 49.

45 Frank H. Easterbrook and Daniel R. Fischel, "The corporate contract. (Contractual Freedom in Corporate Law)", Columbia Law Review, Vol. 89, No. 7, November 1989, hlm. 1417. 
Perlu juga diingat bahwa di Kanada, direktur harus sangat ekstra hati-hati dalam mengambil atau memutuskan untuk tidak mengambil keputusan bisnis, karena tidak sebagaimana di Inggris, ${ }^{46}$ Amerika $^{47}$ Australia $^{48}$ dan Indonesia yang hanya melegalkan gugatan derivatif, di Kanada selain gugatan derivatif, terdapat juga aturan tentang oppression remedy, ${ }^{49}$ dimana pemangku kepentingan non-pemegang saham (nonshareholder stakeholders) termasuk pemegang saham minoritas sekalipun bisa menggugat direktur. ${ }^{50}$ Ini adalah ketentuan yang unik dan hanya ada di Kanada, sebagaimana di atur dalam s 242 (2) the CBCA 2019. Sebagaimana diketahui, dalam gugatan derivatif, pemegang saham yang mewakili jumlah atau porsi tertentu saham, dapat mengajukan gugatan ke pengadilan melawan direktur atau perusahaan. Sedangkan dalam gugatan oppression remedy s 242 (2) the CBCA 2019 menyatakan bahwa penuntut/penggugatnya adalah stakeholder perusahaan yakni bisa seorang pemegang saham atau bekas pemegang saham, direktur atau pejabat perusahaan atau mantan direktur atau pejabat, direktur yang ditunjuk oleh pemerintah untuk menata undang-undang perusahaan, atau orang lainnya, yang dalam pandangan pengadilan adalah orang yang tepat untuk mengajukan gugatan.

Alasan pengajuan oppression remedy menurut s 241 (2) the CBCA 2019 adalah bahwa: a) setiap tindakan atau kelalaian dari perusahaan atau afiliasinya berdampak pada suatu hasil; b) bisnis atau urusan perusahaan atau afiliasinya telah atau telah dilakukan atau dilakukan dengan cara; atau c) wewenang direktur perusahaan atau afiliasinya telah dilaksanakan dengan cara yang menindas atau merugikan secara tidak adil atau secara tidak adil mengabaikan kepentingan pemegang saham, kreditor, direktur atau pejabat. Selengkapnya bunyi s 241 (2) the CBCA 2019 sebagai berikut:

\section{grounds}

(2) If, on an application under subsection (1), the court is satisfied that in respect of a corporation or any of its affiliates

(a) any act or omission of the corporation or any of its affiliates effects a result,

(b) the business or affairs of the corporation or any of its affiliates are or have been carried on or conducted in a manner, or

(c) the powers of the directors of the corporation or any of its affiliates are or have been exercised in a manner that is oppressive or unfairly prejudicial to or that unfairly disregards the interests of any security holder, creditor, director or officer, the court may make an order to rectify the matters complained of.

Menurut s 243 (3) CBCA 2019, Pengadilan memiliki kekuasaan yang sangat luas untuk membuat perintah yang dianggapnya sesuai jika menyimpulkan bahwa telah terjadi tindakan perusahaan atau direktur yang menindas. Pengadilan dapat membuat perintah interim (sementara) atau final untuk: a) menghentikan tindakan yang dikeluhkan; b) menunjuk seorang pengurus/kurator

\footnotetext{
46 James Kirkbride and Steve Letza, "Minority shareholders and corporate governance Reflections on the derivative action in the UK, the USA and in China", International Journal of Law and Management, Vol. 51, No. 4, Juli 2009, hlm. 208-216.

47 Yaad Rotem, "The law applicable to a derivative action on behalf of a foreign corporation-corporate law in conflict", Cornell International Law Journal, Vol. 46, No. 2, Spring 2013, hlm. 322-349.

48 Melissa Hofmann, "The Statutory Derivative Action in Australia: An Empirical Review of its Use and Effectiveness in Australia in Comparison to the United States, Canada and Singapore", Corporate Governance eJournal, http://epublications.bond.edu.au/cgej/13, Mei 2004, hlm. 11-13; Matthew Berkhan, "The Derivative Action in Australia And New Zealand: Will The Statutory Provisions Improve Shareholders' Enforcement Rights?”, Bond Law Review, Vol. 19, No. 1, Januari 1998, hlm. 74-75.

49 Terkait hakikat oppression remedy di Kanada, lihat Brian Cheffins, "The Oppression Remedy In Corporate Law: The Canadian Experience”, University of Pennsylvania Journal of International Business Law, Vol. 10, No. 3, Summer 1998, hlm. 306-313; Jeffrey G. Macintosh, “The Oppression Remedy: Personal or Derivative", Canadian Bar Review, Vol. 70, No. 1, Maret 1991, hlm. 39-52; Jeffrey G. Macintosh, "Bad Faith and the Oppression Remedy: Uneasy marriage, or Amicable Divorce?”, Canadian Bar Review, Vol. 69, No. 2, Juni 1990, hlm. $276-278$.

50 Kim Brooks and Anita I. Anand, "The Allocation of Profits Between Related Entities and the Oppression Remedy: an Analysis of Ford Motor Co. v. Omers", Ottawa Law Review, Vol. 36, No. 1, Winter 2004, hlm. 130-131.
} 
(receiver) atau manajer pengurus; c) mengatur urusan perusahaan dengan mengubah AD/ART atau membuat atau mengubah perjanjian pemegang saham dengan suara bulat; d) mengarahkan penerbitan atau pertukaran saham; e) menunjuk direktur pengganti atau tambahan untuk semua atau salah satu direktur yang menjabat; f) mengarahkan perusahaan untuk tidak membayar pemegang saham atau orang lain, untuk membeli saham dari pemegang saham; g) memerintahkan perusahaan untuk tidak membayar pemegang saham atau orang lain, untuk membayar kepada pemegang saham setiap bagian dari uang yang dibayar oleh pemegang saham untuk sahamnya; $h$ ) perintah yang berbeda atau mengesampingkan suatu transaksi atau kontrak dimana suatu perusahaan merupakan pihak dan mengimbangi perusahaan atau pihak lain manapun dalam transaksi atau kontrak tersebut; i) mewajibkan perusahaan, dalam waktu yang ditentukan oleh pengadilan, untuk memberikan ke pengadilan atau orang yang tertarik dengan laporan keuangan dalam bentuk yang disyaratkan dalam $\mathrm{s}$ 155 atau akuntansi dalam bentuk lain seperti yang ditentukan pengadilan; j) mengarahkan perbaikan register atau catatan lain dari suatu perusahaan; k) melikuidasi dan membubarkan perusahaan; 1) mengarahkan penyelidikan; m) memberi kompensasi kepada orang yang dirugikan; dan $n$ ) mengadili isu-isu tertentu. Dengan diberlakukannya ketentuan oppression remedy ini, direktur di Kanada harus benar mempertimbangkan secara ekstra hatihati keputusan bisnisnya agar terhindar dari gugatan oppression remedy ini.

\section{Business Judgment Rule di Indonesia}

Indonesia jelas mengadopsi BJR dalam UU PT 2007 untuk melindungi direktur dan komisaris. Terkait pertanggungjawaban direktur, diatur secara tegas bahwa direktur bertanggungjawab secara pribadi atau tanggung renteng jika direktur bersalah atau lalai dalam menjalankan tugasnya dengan itikad baik dan penuh tanggungjawab sehingga menimbul kerugian bagi perusahaan (Pasal 97 ayat $(3,4)$ UU PT 2007).
Berdasar Pasal 97 ayat (5) UU PT 2007 disebutkan bahwa direktur tidak dapat dimintai pertanggungjawabannya atas kerugian yang diderita perusahaan jika direktur dapat membuktikan sebaliknya. Rumusan Pasal 97 ayat (5) UU PT 2007 adalah konstruksi UU PT tentang BJR bagi direktur terkait kerugian perusahaan. Pasal 97 ayat (5) UU PT 2007 selengkapnya adalah:

Anggota Direksi tidak dapat dipertanggungjawabkan atas kerugian sebagaimana dimaksud pada ayat (3) apabila dapat membuktikan:

a. kerugian tersebut bukan karena kesalahan atau kelalaiannya;

b. telah melakukan pengurusan dengan itikad baik dan kehati-hatian untuk kepentingan dan sesuai dengan maksud dan tujuan Perseroan;

c. tidakmempunyaibenturankepentingan baik langsung maupun tidak langsung atas tindakan pengurusan yang mengakibatkan kerugian; dan

d. telah mengambil tindakan untuk mencegah timbul atau berlanjutnya kerugian tersebut.

Demikian pula, dalam hal kepalitan, direktur bertanggungjawab secara pribadi atau tanggung renteng untuk membayar semua kewajiban perusahaan yang belum terlunasi dari aset perusahaan jika direktur bersalah atau lalai dalam menjalankan tugasnya sehingga mengakibatkan perusahaan mengalami kebangkrutan. Bahkan tanggungjawab dalam hal kepailitan berlaku surut bagi direktur yakni dalam jangka lima tahun sebelum putusan kepailitan diucapkan (Pasal 104 ayat (2) dan (3) UU PT 2007).

Berdasar Pasal 104 ayat (4) UU PT 2007 disebutkan bahwa direktur tidak dapat dimintai pertanggungjawabannya atas kepailitan perusahaan jika direktur dapat membuktikan sebaliknya. Rumusan Pasal 104 ayat (4) UU PT 2007 adalah konstruksi UU PT tentang BJR bagi direktur terkait kewajiban perusahaan dalam kepailitan. Pasal 104 ayat (4) UU PT 2007 selengkapnya adalah:

Anggota Direksi tidak bertanggungjawab atas kepailitan Perseroan sebagaimana dimaksud 
pada ayat (2) apabila dapat membuktikan:

a. kepailitan tersebut bukan karena kesalahan atau kelalaiannya;

b. telah melakukan pengurusan dengan itikad baik, kehati-hatian, dan penuh tanggung jawab untuk kepentingan Perseroan dan sesuai dengan maksud dan tujuan Perseroan;

c. tidak mempunyai benturan kepentingan baik langsung maupun tidak langsung atas tindakan pengurusan yang dilakukan; dan

d. telah mengambil tindakan untuk mencegah terjadinya kepailitan.

Selanjutnya, terkait pertanggungjawaban komisaris, juga diatur secara tegas bahwa komisaris, bertanggungjawab secara pribadi atau tanggung renteng atas kerugian perusahaan jika komisaris bersalah atau lalai dalam menjalankan tugasnya dengan itikad baik, kehati-hatian, dan bertanggung jawab dalam menjalankan tugas pengawasan dan pemberian nasihat kepada direksi untuk kepentingan Perseroan dan sesuai dengan maksud dan tujuan Perseroan (Pasal 114 ayat (2), (3), dan (4), Pasal 108 ayat (1) UU PT 2007). Namun menurut Pasal 114 ayat (5) UU PT 2007, komisaris tidak dapat dimintai pertanggungjawabannya atas kerugian perusahaan jika komisaris dapat membuktikan sebaliknya. Rumusan Pasal 114 ayat (5) UU PT 2007 adalah konstruksi UU PT tentang BJR bagi komisaris terkait kerugian perusahaan. Pasal 114 ayat (5) UU PT 2007 selengkapnya adalah:

Anggota Dewan Komisaris tidak dapat dipertanggungjawabkan atas kerugian sebagaimana dimaksud pada ayat (3) apabila dapat membuktikan:

a. telah melakukan pengawasan dengan itikad baik dan kehati-hatian untuk kepentingan Perseroan dan sesuai dengan maksud dan tujuan Perseroan;

b. tidak mempunyai kepentingan pribadi baik langsung maupun tidak langsung atas tindakan pengurusan Direksi yang mengakibatkan kerugian; dan

c. telah memberikan nasihat kepada Direksi untuk mencegah timbul atau berlanjutnya kerugian tersebut.
Komisaris dalam hal kepailitan bertanggungjawab secara pribadi atau tanggung renteng untuk membayar semua kewajiban perusahaan yang belum terlunasi dari aset perusahaan jika komisaris bersalah atau lalai dalam menjalankan tugasnya sehingga mengakibatkan perusahaan mengalami kebangkrutan. Bahkan, tanggungjawab dalam hal kepailitan berlaku surut bagi komisaris yakni dalam jangka lima tahun sebelum putusan kepailitan diucapkan (Pasal 115 ayat (1) dan (2) UU PT 2007). Namun, menurut Pasal 115 ayat (3) UU PT 2007, komisaris tidak dapat dimintai pertanggungjawabannya atas kepailitan perusahaan jika komisaris dapat membuktikan sebaliknya. Rumusan Pasal 115 ayat (3) UU PT 2007 adalah konstruksi UU PT tentang BJR bagi komisaris terkait kebangkrutan perusahaan. Pasal 115 ayat (3) UU PT 2007 selengkapnya adalah:

Anggota Dewan Komisaris tidak dapat dimintai pertanggungjawaban atas kepailitan Perseroan sebagaimana dimaksud pada ayat (1) apabila dapat membuktikan:

a. kepailitan tersebut bukan karena kesalahan atau kelalaiannya;

b. telah melakukan tugas pengawasan dengan itikasd baik dan kehati-hatian untuk kepentingan Perseroan dan sesuai dengan maksud dan tujuan Perseroan;

c. tidak mempunyai kepentingan pribadi, baik langsung maupun tidak langsung atas tindakan pengurusan oleh Direksi yang mengakibatkan kepailitan; dan

d. telah memberikan nasihat kepada Direksi untuk mencegah terjadinya kepailitan.

Doktrin BJR juga diadopsi Otoritas Jasa Keuangan bagi perusahaan publik melalui Peraturan Otoritas Jasa Keuangan No. 33/ PJOK.04/2014tentang DireksidanDewanKomisaris Emiten atau Perusahaan Publik, khususnya terkait dengan kerugian perusahaan. Pasal 13 ayat (2) No. 33/PJOK.04/2014 menegaskan bahwa anggota direksi tidak dapat dipertanggungjawabkan atas kerugian Emiten atau Perusahaan Publik jika mampu membuktikan hal-hal berikut: 
a. kerugian terjadi bukan karena karena kesalahan atau kelalaiannya

b. telah melakukan pengurusan dengan itikad baik, penuh tanggungjawab, kehati-hatian untuk kepentingan dan sesuai dengan maksud dan tujuan Emiten/Peruliabilitysahaan Publik;

c. tidak memiliki benturan kepentingan baik langsung maupun tidak langsung; dan

d. telah mengambil tindakan untuk mencegah timbul atau berlanjutnya kerugian.

Jika dicermati berbagai ketentuan dalam UU PT 2007 maupun Peraturan OJK No. 33/ PJOK.04/2014 terkait BJR yang memberikan perlindungan bagi direktur dan komisaris dalam menjalankan tugasnya telah cukup memadai. Hanya saja, tidak sebagaimana yang diatur dalam the CBCA, UU PT 2007 dan POJK No. 33/ PJOK.04/2014, tidak secara eksplisit menggunakan istilah BJR.

Demikian pula, penjelasan elemen-elemen penting BJR dalam UU PT 2007 dan POJK No. 33/ PJOK.04/2014, seolah terpisah dari pelaksanaan tugas untuk bertindak dengan kepedulian dan keahlian (tugas common law direktur) dan tugas untuk bertindak dengan itikad baik dan untuk kepentingan terbaik perusahaan (tugas fidusia direktur). Seharusnya, sebagaimana di Kanada dan Inggris, elemen-elemen penting BJR perlu dijelaskan dengan menghubungankannya dengan tugas common law dan tugas fidusia direktur. Oleh karena itu, dalam perubahan UU PT 2007 yang akan datang, istilah BJR perlu secara tegas dipakai dan penjelasan elemen-elemen penting BJR perlu dikaitkan dengan tugas common law dan tugas fidusia direktur. Selain itu, empat elemen penting BJR dalam UU PT 2007 dan POJK No. 33/PJOK.04/2014 perlu ditambahkan lagi yakni bahwa direktur dan komisaris tidak dapat dituntut jika keputusan bisnis yang diambil telah dilakukan berdasarkan informasi yang cukup, data yang dapat dipercaya dan rasional, tidak mengandung unsur kecurangan, dan tidak mengandung unsur penyalahgunaan kedudukan sebagai direktur atau komisaris dan direktur tidak mengambil keutungan pribadi dari keputusannya.

BJR sebenarnya bisa diterapkan juga di Indonesia melalui mekanisme gugatan derivatif dimana pemegang saham minoritas memiliki kedudukan hukum untuk meminta pertanggungjawaban hukum direktur sebagaimana dimaksud dalam Pasal 97 (6) UU PT 2007 yakni: 'Atas nama Perseroan, pemegang saham yang mewakili paling sedikit 1/10 (satu persepuluh) bagian dari jumlah seluruh saham dengan hak suara dapat mengajukan gugatan melalui pengadilan negeri terhadap anggota Direksi yang karena kesalahan atau kelalaiannya menimbulkan kerugian pada Perseroan'. Penjelasan Pasal 97 ayat (6) UU PT 2007 menyatakan bahwa 'Dalam hal tindakan Direksi merugikan Perseroan, pemegang saham yang memenuhi persyaratan sebagaimana ditetapkan pada ayat ini dapat mewakili Perseroan untuk melakukan tuntutan atau gugatan terhadap Direksi melalui pengadilan'.

Catatan kritis perlu diberikan terkait penggunaaan gugatan derivatif oleh pemegang saham minoritas terkait dengan pelanggaran BJR. Ketentuan di atas jelas menyatakan bahwa gugatan derivatif terhadap direktur atau komisaris yang bertanggungjawab atas kerugian ataupun kebangkrutan perusahaan hanya sema-mata bisa dilakukan oleh pemegang saham minoritas. Penulis berpendapat, ketentuan di atas kurang tepat karena telah membatasi gugatan terkait BJR hanya semata bisa dilakukan oleh pemegang saham minoritas. Ini suatu kelemahan konstruksi BJR dalam UU PT 2007.

Mengapa demikian? Karena untuk menilai dan menentukan pelanggaran duty of care and skill maupun tugas fidusianya, sepanjang terkait penerapan BJR, seharusnya sebagaimana berlaku di Kanada, pemegang saham, baik minoritas maupun pengendali (controlling shareholders) ataupun individu pemegang saham tanpa melihat porsi kepemilikan saham, termasuk kreditur, dapat mengajukan gugatan ke pengadilan jika merasa telah dirugikan oleh tindakan atau keputusan bisnis direktur. 
Sejak berlakunya UU PT tahun 1995 dan tahun 2007, sepanjang pengetahuan penulis, belum ada kasus gugatan derivatif yang sejak awal memang dimaksudkan untuk membuktikan kesalahan direktur dan komisaris terkait keputusan bisnisnya yang dilindungi BJR. Di Indonesia, yang terjadi adalah keputusan bisnis direktur lebih dominan diadili melalui konstruksi pidana korupsi ${ }^{51}$ (bukan gugatan derivatif). Salah satunya ialah tuduhan yang didakwakan kepada Hotasi Nababan (mantan Direktur Utama Merpati Nusantara Airlines). ${ }^{52}$ Dalam kasus Hotasi Nababan Pengadilan Pidana Indonesia memilih mengabaikan penerapan prinsip BJR dan menghukum keputusan bisnis direktur dengan pidana korupsi. Selebihnya, pembahasan mengenai BJR di Indonesia lebih bersifat normatif terkait pengaturannya dalam UU PT 2007. ${ }^{53} \mathrm{Hal}$ tersebut juga masih menyisakan ketidakseragaman pemahaman mengenai BJR di Indonesia baik dikalangan penegak hukum ${ }^{54}$ maupun di kalangan para direktur Badan Usaha Milik Negara (BUMN) yang membuat mereka ragu mengambil keputusan bisnis strategis yang beresiko tinggi. ${ }^{55}$

Sekalipun demikian, sebagaimana disampaikan di bagian pendahuluan, MA telah membuat sebuah terobosan hukum yang luar bisa dengan membebaskan Mantan Direktur Utama Pertamina Karen Agustiawan dari jeratan korupsi dengan pertimbangan BJR. Tepatnya, sesuai penjelasan juru bicara MA, salah satu pertimbangan Hakim MA yang mengadili perkara ini disebutkan bahwa: 'putusan direksi dalam suatu aktivitas perseroan tidak dapat diganggu gugat oleh siapapun. Kendati putusan itu pada akhirnya menimbulkan kerugian bagi perseroan tetapi itu merupakan risiko bisnis. Bertolak dari karakteristik bisnis yang sulit untuk diprediksi (unpredictable) dan tidak dapat ditentukan secara pasti'. ${ }^{56}$

Pertimbangan di atas $^{57}$ memberi pentunjuk yang sangat jelas bahwa MA memilih mengikuti model Inggris dan Kanada, sebagaimana telah dibahas di atas, yang dalam tradisinya melarang pengadilan untuk melakukan second guest atas keputusan bisnis karena pengadilan tidak memiliki keahlian untuk melakukan pengujian tersebut.

\section{Kesimpulan}

Kanada sebagaimana Inggris, telah melakukan kodifikasi duty of care and skill dan tugas fidusia direktur dalam the UK Companies Law 2006 dan the CBCA 2019. Bedanya, di Inggris, dalam kodifikasi tersebut, BJR tidak diadopsi karena telah ada BJD yang dihasilkan oleh pengadilan yang melarang pengadilan melakukan second guest atas keputusan bisnis. Pada pelaksanaannya di Inggris, pengujian atas keputusan bisnis lebih

51 Bambang Sugeng Rukmono and Soehartono, "Some Problems in the Implementation of the Business Judgment Rule Principles to the Directors of State-Owned Enterprises in Indonesia", Advances in Social Science, Education and Humanities Research, 3rd International Conference on Globalization of Law and Local Wisdom (ICGLOW), October 2019, hlm. 233.

52 Muhamad Hafizh Akram \& Nisrina Primadani Fanaro, "Implementasi Doktrin Business Judgement Rule di Indonesia", Ganesha Law Review, Vol. 1, No. 1, Mei 2019, hlm. 86.

53 Sartika Nanda Lestari, "Business Judgment Rule sebagai Immunity Doctrine Bagi Direksi Badan Usaha Milik Negara di Indonesia”, Notarius, Vol. 8, No. 2, September 2015, hlm. 302; Sudarno et al., "Business judgment rule application in company: a comparison based on the case in Indonesia and Malaysia”, IOP Conf. Series: Earth and Environmental Science, 2019, hlm.1; Bewani Octavianisa Masrurah, "Sistem Hukum Perseroan Indonesia Dan Malaysia", Jurnal Ilmu Sosial dan Pendidikan, 2019, 3(3), 183-191, hlm. 183; Gunawan Widjaja, "The Conception and Implementation of "Business Judgment Rule" In Indonesia according to Law No. 40 Year 2007 re. Perseroan Terbatas (Law on PT)", Asian Law Institute Conference, Hongkong, 2009, hlm. 5.

54 Andika Wijaya, "Implementation of the Doctrine of the Business Judgment Rule on Bankruptcy Law in Indonesia", Yuridika, Vol. 35, No. 1, Oktober 2020, hlm.1.

55 Prasetio et al, "Dilemma in the Implementation of Business Judgment Rule in Commercial Transactions of State-Owned Enterprises", Talent Development \& Excellence, Vol. 2, No. 2, Special Issue 2020, hlm. 1541.

56 Detik.com, "MA Lepaskan Eks Dirut Pertamina Karen Di Kasus Korupsi Rp 568 M", Https://News.Detik.Com/Berita/D-4931904/MaLepaskan-Eks-Dirut-Pertamina-Karen-Di-Kasus-Korupsi-Rp-568-M?_Ga=2.21407481.332223227.1583567161-84216239.1549435714, diakses 9 Maret 2020. Lihat juga Kompas.com, “Eks Dirut Pertamina Bebas karena Risiko Bisnis, Kasus Jiwasraya Bernasib Sama?”, https://nasional.kompas.com/read/2020/03/11/09415771/eks-dirut-pertamina-bebas-karena-risiko-bisnis-kasus-jiwasraya-bernasibsama? page $=$ all, diakses 12 Maret 2020 .

57 Disarankan agar dibaca pertimbangan hakim dan diktum putusan MARI secara utuh dan mengkaitkannya dengan fakta persidangan untuk memastikan koherensi antara fakta, pertimbangan dan putusannya. Sayang sekali, hingga saat Artikel ini ditulis, putusan ini belum bisa diakses di Website MARI. 
merupakan pengujian terhadap apakah keputusan bisnis direktur telah melanggar tugas-tugas direktur sebagaimana di atas dalam the UK Companies Law 2006.

Sementara di Kanada, BJR dikodifikasi bersamaan dengan tugas direktur dalam the CBCA 2019 dimana terdapat delapan elemen mendasar BJR di Kanada yakni a) keputusan harus dilakukan dengan penuh kehati-hatian, kepedulian dan keahlian; b) keputusan dilakukan berdasarkan informasi yang cukup; c) direktur harus bertindak jujur dan dengan itikad baik; d) direktur mengelola perusahaan untuk mencapai tujuan perusahaan; e) direktur harus menghidari konflik kepentingan; f) direktur harus menghindari penyalahgunaan posisi sebagai direktur untuk memperoleh manfaat pribadi; g) direktur haus menjaga rahasia perusahaan; dan $h$ ) direktur harus melayani perusahaan tanpa pamrih, jujur dan loyal.

BJR juga diadopsi di Indonesia dalam UU PT 2007 dan Peraturan OJK di tahun 2014 dimana unsur-unsur BJR dirumuskan dengan baik. Namun terdapat rekomendasi bagi perumusan ulang BJR dalam UU PT 2007 dimasa yang akan datang. Pertama, UU PT perlu secara tegas membuat pasalpasal khusus terkait BJR dan menggunakan istilah
BJR secara eksplisit sebagaimana dilakukan di Inggris dan Kanada. Hal ini dimaksudkan untuk menghindari penafsiran yang tidak konsisten di kalangan penegak hukum di Indonesia.

Kedua, unsur BJR dalam UU PT perlu ditambahkan yakni bahwa direktur dan komisaris tidak dapat dituntut jika keputusan bisnisnya telah dilakukan berdasarkan informasi yang cukup, data yang dapat dipercaya dan rasional, tidak mengandung unsur kecurangan, dan tidak mengandung unsur penyalahgunaan kedudukan sebagai direktur atau komisaris, dan direktur tidak memperoleh keuntungan pribadi dari keputusannya. Ketiga, Pemerintah dan DPR perlu mempertimbangkan perumusan ulang konsep BJR secara lebih tegas dan rinci seperti di atas sehingga tidak menimbulkan tafsir bebas yang menyesatkan di kalangan penegak hukum dan untuk menghindari potensi kriminalisasi keputusan bisnis direktur. Keempat, UUPT perlu memperluas pihak yang dapat atau berhak mengajukan gugatan kepada direktur dalam hal pelanggaran unsur-unsur BJR yakni pemegang saham baik minoritas, pengendali atau individu, termasuk kreditur, pekerja atau pelanggan, atau siapapun yang memiliki kepentingan (stake) dengan perusahaan (stakeholders umumnya).

\section{DAFTAR PUSTAKA}

\section{A. Buku}

Block, Dennis J. et al, 1987, The Business Judgment Rule - Fiduciary Duties of Corporate Directors and Officers, Prentice Hall, Clifton N.J.

Farrar, John, H., 2001, Corporate Governance Theories, Principles, and Practices, $2^{\text {nd }}$ edn, Oxford University Press, Oxford.

Enriques, Luca; Hansmann, Henry; and Kraakman, Reinier, 2001, The Basic Governance Structure: The Interests of Shareholders as a Class, in Kraakman et al, The Anatomy of Corporate Law: A Comparative and Functional Approach, 3rd edn, Oxford University Press, Oxford.
Rissy, Yafet Y. W., 2020, Corporate Governance: Kajian Teori, Konsep dan Praktek Terbaik Lintas Yurisdiksi, Perspektif International Serta Tantangannya, Griya Media, Salatiga, hlm. 307-312.

\section{B. Artikel Jurnal}

Akram, Muhamad Hafizh \& Fanaro, Nisriina Primadani, "Implementasi Doktrin Business Judgement Rule di Indonesia", Ganesha Law Review, Vol. 1, No.1, Mei 2019.

Armour, John and Skeel, David, "Who Should Write Hostile Takeovers, and Why? The Peculiar Divergence of US and UK Takeover Regulation" Georgetown Law Journal, Vol. 
95, No. 7, Agustus 2007.

Arsalidou, Demetra, “Objectivity Vs Flexibility in Civil Law Jurisdictions and The Possible Introduction of The Business Judgment Rule In English Law", The Company Lawyer, Vol. 24, No. 8, Agustus 2003.

Bainbridge, Stephen M., "The Business Judgment Rule as Abstention Doctrine", Vanderbilt Law Review, Vol. 57, No. 1, Januari 2004.

Berger, David J., "Exporting the Twin Towers: The Development of Transnational Business Judgment Rule". Saint Louis University Public Law Review, Vol. 9, No. 1, Spring 1990.

Berkhan, Matthew, "The Derivative Action in Australia And New Zealand: Will The Statutory Provisions Improve Shareholders' Enforcement Rights?", Bond Law Review, Vol. 19, No. 1, Januari 1998.

Branson, M. Douglas, "The Rule at Isn't a Rule - Business Judgment Rule", Alparaiso University Law Review, Vol. 36, No. 34, Summer 2002.

Brooks, Kim and Anand, Anita I., "The Allocation of Profits Between Related Entities and the Oppression Remedy: An Analysis of Ford Motor Co. v. Omers", Ottawa Law Review, Vol. 36, No. 1, Winter 2004.

Cheffins, Brian, "The Oppression Remedy in Corporate Law: The Canadian Experience", University of Pennsylvania Journal of International Business Law, Vol. 10, No. 3, Summer 1998.

Demmoth, Deborah A., "Directors' Duty of Care and the Business Judgment Rule: American Precedents and Australian Choices", Bond Law Review, Vol. 4, No. 2, 1992.

Donaldson, Lex and Davis, James H., "Stewardship Theory or Agency Theory: CEO governance and shareholder returns", Australian Journal of Management, Vol. 16, No. 1, Juni 1991.

Farrar, John, H., "Business Judgment and Defensive Tactics in Hostile Takeover Bids", Canadian
Business Law Journal, Vol. 15, No. 1, Maret 1989.

Frank H. Easterbrook and Daniel R. Fischel, "The corporate contract. (Contractual Freedom in Corporate Law)", Columbia Law Review, Vol. 89, No. 7, November 1989.

Giraldo, Laguado Andrés, Carlos, "Factors governing the application of the business judgment rule: an empirical study of the US, UK, Australia and the EU" en Vniversitas, Vol. 111, 2006.

Gurrea-Martinez, Aurelio, "Re-examining the law and economics of the business judgment rule: Notes for its implementation in nonUS jurisdictions", Journal of Corporate Law Studies, Vol. 18, No. 2, July 2018.

Hinsey IV, Joseph, "Business Judgment and the American Law Institute's Corporate Governance Project: The Rule, The Doctrine and the Reality". George Washington Law Review, Vol. 15, No. 4-5, May 1984.

Hofmann, Melissa, "The Statutory Derivative Action in Australia: An Empirical Review of its Use and Effectiveness in Australia in Comparison to the United States, Canada and Singapore", Corporate Governance eJournal, http://www.austlii.edu.au/au/ journals/ElderLRev/2005/1.pdf, Mei 2004.

Horrigan, Bryan, "Directors' Duties and Liabilities - Where Are We Now and Where Are We Going in the UK, Broader Commonwealth, and Internationally?", International Journal of Business and Social Science, Vol. 3, No. 2, Januari 2012.

Howard, John, "Takeover battles and the business judgment rule: recent American case law development", Canadian Business Law Journal, Vol.11, No. 4, Agustus 1986

Hu, Pamela L., \& C. Silberglied, Russell, "From Production Resources to Peoples Department Stores: A Similar Response by Delaware and Canadian Courts on the Fiduciary Duties of Directors to Creditors of Insolvent Companies", Journal of Business and 
Technology Law, Vol. 1, No. 2, 2007.

Jensen, Michael C. and Meckling, William H., "Theory of the firm: Managerial behaviour, agency costs and ownership structure", Journal of Financial Economics, Vol. 3, No. 4, 1976.

Johnson, Lyman P.Q., "Corporate Officers and The Business Judgment Rule", Business Lawyer, Vol. 60, No. 2, Februari 2005.

Johnson, Lyman P.Q., "Unsettledness in Delaware Corporate Law: Business Judgment Rule, Corporate Purpose", Delaware Journal of Corporate Law, Vol. 38, No. 2, Spring 2013.

Keay, Andrew, \& Loughrey, Joan, "The Concept of Business Judgment”, Legal Studies, Vol. 39, No. 1, Maret 2019.

Kirkbride, James and Letza, Steve, "Minority shareholders and corporate governance Reflections on the derivative action in the UK, the USA and in China", International Journal of Law and Management, Vol. 51, No. 4, Juli 2009.

Lestari, Sartika Nanda, "Business Judgment Rule Sebagai Immunity Doctrine Bagi Direksi Badan Usaha Milik Negara di Indonesia", Notarius, Vol. 8, No. 2, September 2015.

Macintosh, Jeffrey G., "The Oppression Remedy: Personal or Derivative", Canadian Bar Review, Vol. 70, No. 1, Maret 1991.

Macintosh, Jeffrey G., "Bad Faith and the Oppression Remedy: Uneasy marriage, or Amicable Divorce?", Canadian Bar Review, Vol. 69, No. 2, Juni 1990.

Masrurah, Bewani Octavianisa, "Konsep Itikad Baik Dalam Penerapan Business Judgment Rule Berdasarkan Sistem Hukum Perseroan Indonesia Dan Malaysia', Jurnal Ilmu Sosial dan Pendidikan, Vol. 3, No. 3, November 2019.

McMillan, Lori, “The Business Judgment Rule as an Immunity Doctrine". William and Mary Business Law Review, Vol. 4, No. 2, Agustus 2013.
MP, Ponsford, "Corporate Governance and the Business Judgment Rule: Fiduciary Duties of Directors in Canada and the People's Republic of China". Journal of Civil Legal Science, Vol. 5, No. 1, Januari 2016.

Miller, Geoffrey, "Special Symposium Issue: Political Structure and Corporate Governance: Some Points of Contrast Between the United States and England", Columbia Business Law Review, Vol. 1, Winter 1998.

Ponta, Adina, \& Catana, Radu, N., "The Business Judgement Rule and Its Reception in European Countries", The Macrotheme Review, Vol. 4, No. 7, Winter 2015.

Prasetio, et al., "Dilemma in the Implementation of Business Judgment Rule in Commercial Transactions of State-Owned Enterprises", Talent Development \& Excellence', Vol. 2, No. 2, Special Issue 2020.

Riley, Christopher, "Derivative claims and ratification: time to ditch some baggage", Legal Studies, Vol. 34, No. 4, Desember 2013.

Rissy, Yafet Yosafet Wilben, "Ketentuan dan Pelaksanaan Business Judgement Rule di Amerika, Australia dan Indonesia", Jurnal Masalah-Masalah Hukum, Vol. 49, No. 2, April 2020.

Ross, Stephen A., "The economic theory of agency: The principal's problem", American Economic Review, Vol. 63, No. 2, Mei 1973.

Rotem, Yaad, "The law applicable to a derivative action on behalf of a foreign corporationcorporate law in conflict", Cornell International Law Journal, Vol. 46, No. 2, Spring 2013.

Rukmono, Bambang Sugeng dan Soehartono, "Some Problems in the Implementation of the Business Judgment Rule Principles to the Directors of State-Owned Enterprises in Indonesia", Advances in Social Science, Education and Humanities Research, Oktober 2019. 
Sudarno et al, "Business judgment rule application in company: a comparison based on the case in Indonesia and Malaysia", IOP Conf. Series: Earth and Environmental Science, 2019.

Stout, Lynn A., "In Praise of Procedure: An Economic and Behavioral Defense Of Smith V. Van Gorkom And The Business Judgment Rule", Northwestern University Law Review, Vol. 96, No. 2, Winter 2002.

Vasudev, P.M., "Corporate Stakeholders in Canada-An Overview and a Proposal", Ottawa Law Review, Vol. 45, No. 1, Spring 2014.

Weinberger, Lael Daniel, "The Business Judgment Rule and Sphere Sovereignty", Thomas M. Cooley Law Review, Vol. 27, No. 2, Mei 2010.

Widjaja, Gunawan, "The Conception and Implementation of "Business Judgment Rule" In Indonesia according to Law No. 40 Year 2007 re. Perseroan Terbatas (Law on PT)", Asian Law Institute Conference, Hongkong, 2009.

Wijaya, Andika, "Implementation of the Doctrine of the Business Judgment Rule on Bankruptcy Law in Indonesia", Yuridika, Vol. 35, No. 1, Oktober 2020.

\section{Peraturan Perundang-Undangan}

Undang-Undang Nomor 40 Tahun 2007 tentang Perseroan Terbatas (Lembaran Negara Tahun 2007 Nomor 106, Tambahan Lembaran Negara Republik Indonesia Nomor 4756).

Peraturan Otoritas Jasa Keuangan Nomor 33/ PJOK.04/2014 tentang Direksi dan Dewan Komisaris Emiten atau Perusahaan Publik.

\section{Internet}

Aronson v. Lewis, 473 A.2d 805, 812 (Del. 1984), "Supreme Court of Delaware". Decided: March 1, 1984, IV, https://law.justia.com/ cases/delaware/supreme-court/1984/473-a- 2d-805-4.html, diakses pada 30 Juli 2020.

Detik.com, "MA Lepaskan Eks Dirut Pertamina Karen di Kasus Korupsi Rp 568 M", https://news.detik.com/berita/d-4931904/ ma-lepaskan-eks-dirutpertaminakaren-di-kasus-korupsi-rp $568 m$ ? $g a=2.21407481 .332223227 .1583567161-$ 84216239.1549435714, diakses pada 9 Maret 2020.

Kames, Lord Henry Home, "Principles of Equity", https://quod.lib.umich.edu/e/ecco/0048414 31.0001.000/1:8? rgn=div1; view=fulltext $>$, diakses pada 2 September 2019.

Kerr v. Danier Leather Inc., SCC 44 (CanLII), [2007] 3 SCR 331. https://www.canlii.org/ en/ca/scc/doc/2007/2007scc44/2007scc44. html, diakses pada 30 Juli 2020.

Kompas.Com, "Eks Dirut Pertamina Bebas karena Risiko Bisnis, Kasus Jiwasraya Bernasib Sama?", https://nasional.kompas. com/read/2020/03/11/09415771/eks-dirutpertamina-bebas-karena-risiko-bisniskasus-jiwasraya-bernasib-sama?page $=$ all, diakses pada 12 Maret 2020.

Maple Leaf Foods Inc. v. Schneider Corp., 1998 CanLII 5121 (ON CA), 42 O.R. (3d) 177 (C.A.). https://www.canlii.org/en/on/onca/ doc/1998/1998canlii5121/1998canlii5121. html, diakses pada 30 Juli 2020.

Peoples Department Stores Inc. (Trustee of) v. Wise, [2004] SCC 68, [2004] 3 SCR, https://scc-csc.lexum.com/scc-csc/scc-csc/ en/item/2184/index.do, diakses pada 1 September 2019.

Re City Equitable Fire Insurance Co [1925] Ch 407, https://www.revolvy.com/page/Re-CityEquitable-Fire-Insurance-Co, diakses pada 2 September 2019.

\section{E. Dokumen Resmi Lain}

The UK Companies Act 2006

The Canadian Business Corporation Act 2019. 